\title{
Cerebral Localized Marginal Zone Lymphoma Presenting as Hypothalamic-Pituitary Region Disorder
}

\author{
E. Broussalis ${ }^{\mathrm{a}} \quad$ J. Kraus ${ }^{\mathrm{a}} \quad$ A.B. Kunz ${ }^{\mathrm{a}} \quad$ G. Luthringshausen ${ }^{\mathrm{a}}$ \\ M. McCoy ${ }^{b}$ W. Muss ${ }^{c} \quad$ G. Hutarew ${ }^{c} \quad$ G. Ladurner ${ }^{d}$ \\ E. Trinka ${ }^{a} \quad$ M. Killer-Oberpfalzer ${ }^{a}$ d
}

Departments of a Neurology and ${ }^{b}$ Radiology, Christian Doppler Klinik, Paracelsus Medical University, 'Department of Pathology, St. Johanns Spital, Paracelsus Medical University, and ${ }^{\mathrm{d}}$ Neuroscience Institute, Christian Doppler Klinik, Salzburg, Austria

\section{Key Words}

Bronchus-associated lymphoid tissue - Lymphoma - Olfactory disorder · Symptomatic psychosis · Diabetes insipidus · Mesencephalon

\begin{abstract}
Introduction: Marginal zone B-cell lymphoma is a rare disease which can be considerably difficult to recognize and diagnose when signs of systemic involvement are absent.

Case Presentation: We report the case of a 57-year-old woman with initial olfactory disturbance, followed by psychosis, diabetes insipidus and hypothalamic eating disorder as an uncommon clinical presentation of marginal zone B-cell lymphoma.

Conclusion: Marginal zone B-cell lymphoma should be considered as a potential differential diagnosis in patients with hypothalamic disturbances.
\end{abstract}

\section{Introduction}

Marginal zone B-cell lymphoma (MZBCL) is a rare disease which can be considerably difficult to recognize and diagnose when signs of systemic involvement are absent. Mucosa-associated lymphoid tissue (MALT) refers to lymphoid tissue located within the epithelial layer of the gastrointestinal, respiratory and urogenital tracts, and their associated connective tissue [1]. The disease may disseminate within the MALT (diffuse involvement of a single MALT site or multiple mucosal localizations) or may spread outside the MALT (lymph node and bone marrow involvement) as a result of the loss of 
mucosal homing properties $[2,3]$. When localized within the respiratory tract, the lymphoma is referred to as bronchus-associated lymphoid tissue (BALT) lymphoma [1].

MZBCL accounts for 5-17\% of all non-Hodgkin lymphomas in adults, depending on the series. MALT lymphoma is the most frequent of the MZBCL subtypes, accounting for $50-70 \%$ of MZBCL and 7-8\% of non-Hodgkin lymphomas. Splenic and nodal MZBCL represent 20 and $10 \%$ of MZBCL, respectively, and account for less than $1 \%$ of nonHodgkin lymphomas [4]. Those lymphomas are described as indolent disorders that typically affect patients of middle and advanced age, predominantly women [2, 4-7].

However, the classification of the disseminated stage in nongastric MALT lymphomas remains a controversial issue: in the Lyon series, $52 \%$ of patients were reported to have an advanced lymphoma and $25 \%$ showed bone marrow involvement [2], whereas in the International Extranodal Lymphoma Study Group study, the percentages were considerably lower (27 and 14\%, respectively) [3].

\section{Case Report}

A 57-year-old woman presented at our outpatient department in March 2008 with olfactory hallucinations, recurrent diplopia, frontal cephalea, short-term memory dysfunction, lack of appetite and a weight loss of $14 \mathrm{~kg}$ since September 2007. Her medical history included hypothyreosis. Neurological investigations additionally revealed a left-sided ptosis. Cranial gadolinium-enhanced MRI scans showed normal findings, and laboratory test results were within the normal range.

In June 2008, the patient presented with persisting symptoms and new onset depression. Laboratory tests, including a vasculitis screening, did not show pathological findings, except for the diagnosis of secondary hypothyreosis. A repeated cranial gadolinium-enhanced MRI (3T Philips Archieva MRI using NV16 coil) scan revealed an edema localized in the hypothalamic region and extending into the mesencephalon and the anterior commissure up to the mammillary bodies, with a slightly hypointense signal on unenhanced T1 sequences. A conglomerated ring enhancement in an area of about $14 \times 8 \times 10$ mm was found. Single voxel proton MRI spectroscopy (TE144 and TE35) revealed a depressed N-acetyl aspartate peak and an elevated choline peak. Cerebrospinal fluid analysis showed mild pleocytosis (8 cells/ $\mu \mathrm{l}$ ) and a normal angiotensin-converting enzyme level. Flow cytometric cerebrospinal fluid analyses were normal. A cranial F18 FDG PET/CT scan showed a highly increased metabolism within the lesion (table 1). A fine needle aspiration biopsy of the brain was performed, which revealed only nonspecific inflammation. The patient received antidepressants (SSRI) and L-thyroxine for hypothyreosis.

Since September 2008, our patient had developed polydipsia (10 l/day) as well as an eating disorder (polyphagia) with consecutive weight gain. Treatment with desmopressin acetate and dimethicone was initiated by her physician.

In May 2009, the patient presented with distinctive disorientation, optical hallucinations, illusions and compulsive buying behavior. Repeated MRI showed unchanged results, except for a decrease of the collateral edema (fig. 1). Treatment for secondary partial adrenal cortex insufficiency with desmopressin acetate, L-thyroxine and dimethicone was continued, and an adjunctive therapy with hydrocortisone and risperidone was introduced. Laboratory tests showed elevated angiotensinconverting enzyme levels $(77.90 \mathrm{U} / \mathrm{ml})$. A thoracic CT scan revealed mediastinal lymph nodes and peribronchial condensations - suggestive of sarcoidosis. A bronchoalveolar lavage revealed a BALT lymphoma (extranodal marginal zone lymphoma) (fig. 1). Bone marrow puncture was performed to confirm the diagnosis and showed unremarkable findings. An abdominal CT scan revealed intraabdominal pathological lymph nodes. Iliac lymph node biopsy confirmed the diagnosis of MZBCL (see table 1).

MZBCL, with an associated hypothalamic lesion, was diagnosed. As a result, she was started on 3 cycles of cladribine therapy $(0.12 \mathrm{mg} / \mathrm{kg})$. 
The patient showed an improvement during the follow-up examinations over a period of 4 months; however, severe psychological deficits and a secondary partial adrenal cortex insufficiency persisted. The psychological deficits included short-term memory disturbances, slight optical hallucinations, depression and a remarkable reduced obsessive-compulsive disorder. Psychological symptoms remained stable under medical treatment with risperidone and antidepressants (SSRI).

Restaging thoracic and abdominal CT scans in September 2009 showed no pathological findings. Bronchoalveolar lavage from October 2009 revealed normal results. In the cerebral MRI scans (performed 2 months after cladribine therapy), the enhancing lesions had disappeared.

\section{Discussion}

We present the first case of MZBCL with hypothalamic-pituitary region disorder, olfactory disorder and psychosis. Previously, intracranial MZBCL was occasionally referred to as dural lymphoma [8].

In addition to the occurrence in the lungs, primary tumor manifestation of MZBCL is often localized in the stomach, the parotid glands and the lachrymal glands [1]. Typically, middle-aged women are affected [8]. MZBCL has been reported to be induced by pathologic conditions such as chronic or recurrent respiratory infections, smoking and chronic hypersensitivity pneumonitis [9]. Lesions within the hypothalamic-pituitary region are often associated with neurological symptoms, secondary mass effect, hormonal excess and/or deficiencies or might also be an isolated radiographic finding [10].

In our patient, the fine needle aspiration biopsy of the brain was not conclusive in making the diagnosis of lymphoma, although the biopsy samples were retrieved from the affected brain regions. Biopsy results only revealed an unspecific inflammation, which may have been attributable to a high infiltration of microglia and macrophages.

It has been previously described that needle aspiration biopsy of the brain might show misleading results in the diagnosis of cerebral lymphoma [11]. One study analyzed fine needle aspiration biopsy results in 494 patients, and revealed that the overall accuracy rate of fine needle aspiration cytology, whether malignant or benign, was $91.89 \%$, whilst the diagnostic accuracy for the exact type of tumor was $87.16 \%$. Furthermore, $12.6 \%$ of the fine needle aspiration specimens proved to be inadequate for diagnosis [12].

Differential diagnosis of cerebral lymphoma often includes sarcoidosis, cerebral malignancies, angiitis and granulomatous disease [1]. According to the literature, cladribine has been proven to be effective as a first-line treatment for MZBCL $[9,13,14]$.

\section{Conclusion}

We have demonstrated that in patients with hypothalamic-pituitary region disorder, olfactory disorder and psychosis, MZBCL should be considered as a rare but crucial differential diagnosis. 
Table 1. Clinical course of a 57-year-old female with an uncommon clinical presentation of a primary cerebral MZBCL consisting of initial olfactory disorder, followed by an organic psychosyndrome, diabetes insipidus as well as a hypothalamic eating disorder

\begin{tabular}{|c|c|c|}
\hline & June 2008 & May 2009 \\
\hline Laboratory findings & $\begin{array}{l}\text { normal white blood cell count, red blood } \\
\text { cell count, hemoglobin, platelets, creatinine, } \\
\text { electrolytes, glucose, liver parameters, } \\
\text { ELISA for HIV, C-reactive protein }\end{array}$ & $\begin{array}{l}\text { normal white blood cell count, red blood } \\
\text { cell count, hemoglobin, platelets, } \\
\text { creatinine, electrolytes, glucose, liver } \\
\text { parameters, ELISA for HIV, C-reactive } \\
\text { protein }\end{array}$ \\
\hline Tumor markers & $\begin{array}{l}\text { normal CEA, AFP, CA 19-9, CA 15-3, } \\
\text { CA } 125\end{array}$ & - \\
\hline Cerebrospinal fluid analysis & $\begin{array}{l}\text { normal protein and glucose levels, lactate } \\
\text { mild pleocytosis } 8 \text { cells } / \mu \mathrm{l}\end{array}$ & - \\
\hline $\begin{array}{l}\text { Virology of cerebrospinal fluid and } \\
\text { laboratory findings }\end{array}$ & $\begin{array}{l}\text { normal, negative results for early summer } \\
\text { meningoencephalitis, varicella zoster virus, } \\
\text { Epstein-Barr virus, cytomegalic virus, } \\
\text { toxoplasmosis, Borrelia burgdorferi, HIV }\end{array}$ & - \\
\hline $\begin{array}{l}\text { Flow cytometric cerebrospinal fluid } \\
\text { analysis }\end{array}$ & $\begin{array}{l}\text { no findings indicating sarcoidosis or } \\
\text { lymphoma }\end{array}$ & - \\
\hline Listeria monocytogenes PCR & negative & - \\
\hline Erythrocyte sedimentation rate & $20 \mathrm{~mm}$ & $58 \mathrm{~mm}$ \\
\hline Fungal and tuberculosis culture & negative & - \\
\hline Chest X-ray & normal & normal \\
\hline Angiotensin-1-converting enzyme & $58.70 \mathrm{U} / \mathrm{ml}$ & $77.90 \mathrm{U} / \mathrm{ml}$ \\
\hline Urinanalysis & normal & normal \\
\hline Abdominal sonography & no signs of lymphadenopathy & - \\
\hline Vasculitis screening tests & $\begin{array}{l}\text { normal antinuclear antibodies, c-ANCA, } \\
\text { p-ANCA, C3, C4 }\end{array}$ & - \\
\hline Thyroid hormones & $\begin{array}{l}\text { TSH: } 0.11 \mathrm{U} / \mathrm{ml}, \mathrm{T} 3: 3.75 \mathrm{U} / \mathrm{ml} \text {, } \\
\text { T4: } 0.83 \mathrm{U} / \mathrm{ml}\end{array}$ & $\begin{array}{l}\text { TSH: }<0.01 \mathrm{U} / \mathrm{ml}, \mathrm{T} 3: 1.35 \mathrm{U} / \mathrm{ml} \text {, } \\
\text { T4: } 4.30 \mathrm{U} / \mathrm{ml}\end{array}$ \\
\hline Hypothalamic hormones & $\begin{array}{l}\text { normal ACTH, HGH, ADH, IGF-1, } \\
\text { cortisol, LH, FSH, prolactin }\end{array}$ & $\begin{array}{l}\text { normal ACTH, HGH, ADH }(<5 \mathrm{pg} / \mathrm{ml}) \text {, } \\
\text { IGF-1, cortisol, LH, FSH, prolactin }\end{array}$ \\
\hline Borrelia burgdorferi test & $\begin{array}{l}\text { normal in cerebrospinal fluid analysis and } \\
\text { serum }\end{array}$ & - \\
\hline Thyroid sonography & $\begin{array}{l}\text { inhomogeneous echo pattern, consistent } \\
\text { with a secondary hypothyreosis }\end{array}$ & - \\
\hline EEG & normal & normal \\
\hline Transthoracic echocardiography & normal & normal \\
\hline Cranial CT scan & no bone lesions & - \\
\hline $\begin{array}{l}\text { Gadolinium-enhanced cerebral MRI } \\
\text { scan }\end{array}$ & $\begin{array}{l}\text { edema localized in the hypothalamus } \\
\text { reaching up to the mesencephalon and } \\
\text { commissura anterior to the corpora } \\
\text { mammillaria, with intense granular } \\
\text { phenotypic changes }\end{array}$ & $\begin{array}{l}\text { no alteration of the hypothalamic lesion, } \\
\text { no significant edema }\end{array}$ \\
\hline
\end{tabular}




\begin{tabular}{|c|c|c|}
\hline MRI spectroscopy & $\begin{array}{l}\text { depressed NAA peak and higher choline } \\
\text { peak }\end{array}$ & - \\
\hline Cranial PET/CT examination & $\begin{array}{l}\text { spotted focal hypermetabolism, indicating } \\
\text { that the lesion has higher malignant parts }\end{array}$ & - \\
\hline Carotid and vertebral sonography & mild atherosclerosis & mild atherosclerosis \\
\hline $\begin{array}{l}\text { Cerebral fine needle aspiration } \\
\text { biopsy histology }\end{array}$ & $\begin{array}{l}\text { unspecific inflammation attributable to } \\
\text { high infiltration with microglia and } \\
\text { macrophages; } \\
\text { no evidence of lymphoma or sarcoidosis }\end{array}$ & - \\
\hline Thoracic CT scan & - & $\begin{array}{l}\text { mediastinal lymph nodes, peribronchial } \\
\text { condensations, changes indicating } \\
\text { sarcoidosis }\end{array}$ \\
\hline Liver sonography & - & hepatopathy \\
\hline Bronchoalveolar lavage & - & $\begin{array}{l}\text { BALT lymphoma (monomorphic } \\
\text { lymphoid cells) }\end{array}$ \\
\hline
\end{tabular}

Follow-Up Investigations after Diagnosis of BALT Lymphoma

Bone marrow puncture, June 2009 normal

\begin{tabular}{|c|c|c|}
\hline Iliac lymph node biopsy, July 2009 & BALT lymphoma & - \\
\hline Abdominal CT scan, June 2009 & - & intra-abdominal pathological lymph nodes \\
\hline Cerebrospinal fluid analysis, July 2009 & $\begin{array}{l}\text { normal } \\
\text { mild pleocytosis } 8 \text { cells } / \mu l\end{array}$ & - \\
\hline Restaging CT scan, September 2009 & normal, no lymph nodes & - \\
\hline Bronchoalveolar lavage, October 2009 & normal & - \\
\hline Cerebral MRI scan with gadolinium & normal & - \\
\hline \multicolumn{3}{|c|}{$\begin{array}{l}\text { ELISA = Enzyme-linked immunosorbent assay; TSH = thyroid-stimulating hormone; } \mathrm{PCR}=\text { polymerase chain reaction; } \\
\text { HIV = human immunodeficiency virus; c-ANCA = anticytoplasmic antibodies; } \text { - } \text {-ANCA = antiperinuclear antibodies; } \mathrm{ACTH}= \\
\text { adrenocorticotropic hormone; HGH = human growth hormone; } \mathrm{ADH}=\text { antidiuretic hormone; } \mathrm{LH}=\text { luteinizing hormone; } \\
\text { FSH = follicle-stimulating hormone; CEA = carcinoembryonic antigen; AFP = } \alpha \text {-fetoprotein; CA } 19-9=\text { carbohydrate antigen } \\
\text { 19-9; CA 15-3 = cancer antigen 15-3; CA } 125 \text { = cancer antigen } 125 \text {. }\end{array}$} \\
\hline
\end{tabular}



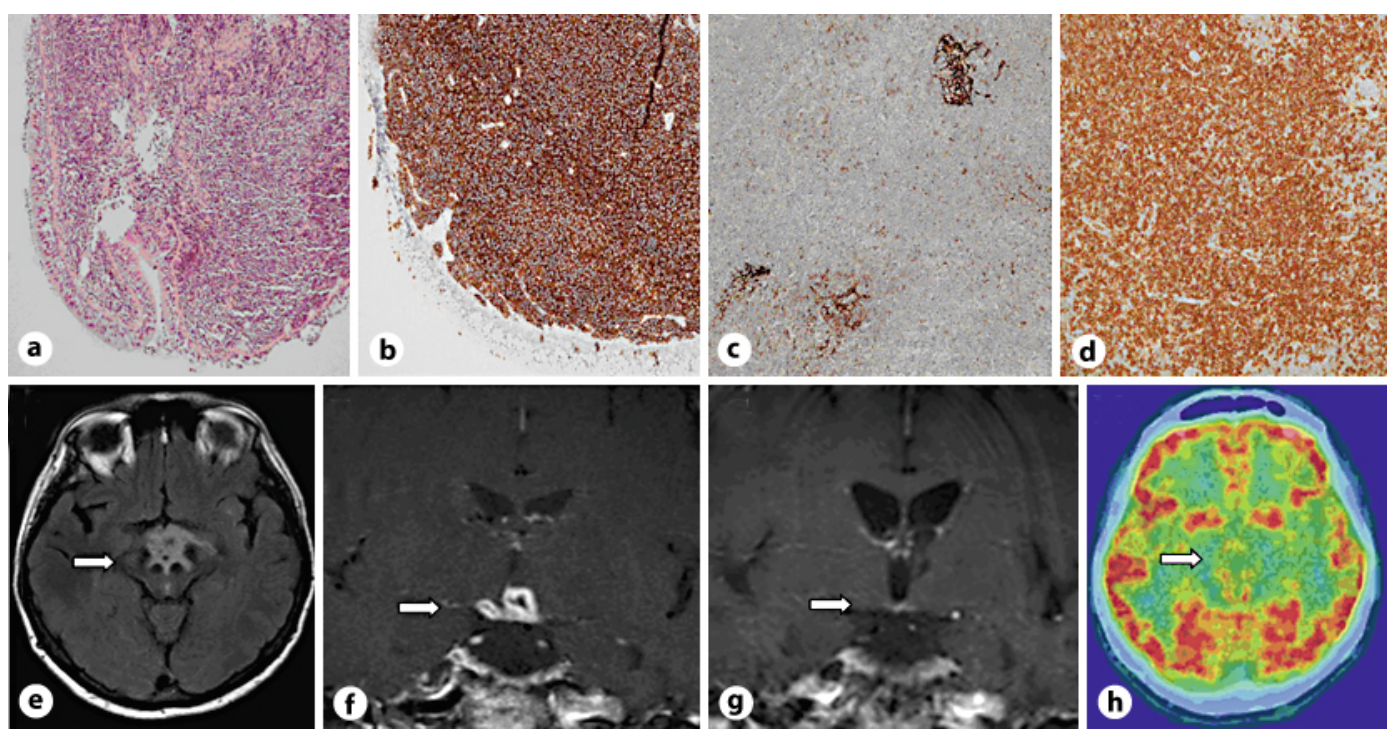

Fig. 1. a-d Histological slides from the biopsy were routinely stained with $\mathrm{HE}$ and Giemsa stain. Under the bronchial epithelium, a dense lymphatic infiltrate of small indistinct, round lymphocytes interspersed with some monocytoid lymphocytes was seen (cf. a). The Ki-67 proliferation was found to be low (not shown). Subsequent immunohistochemical (IHC) staining of lung tissue for CD20 (cf. b) was strongly positive. IHC staining for CD23 in lymph node material was positive only for residual follicle centers showing faint staining (cf. c). The expression of CD43 in lymph node tissue displayed strong expression in neoplastic cells (cf. d). Further IHC staining excluded small lymphocytic lymphoma, mantle cell lymphoma and follicular lymphoma. a Lung: histological overview, bronchial epithelium to the left. b Lung: CD20 IHC staining. c Lymph node: CD23 IHC staining. d Lymph node: CD43 IHC staining. e Flair sequence with hyperintense edema in the hypothalamic area reaching into the mesencephalon. f Contrast-enhanced T1 TSE sequence shows a conglomerate ring-enhancing lesion and enhancement of the oculomotor nerves. $g$ No contrast enhancement in the T1 TSE sequence after cladribine therapy. $\mathbf{h}$ Cranial F18 FDG PET/CT scan shows spotted focal hypermetabolism.

\section{References}

1 Young AB, Kyung SL, Joungho H, Young-Hyeh K, Byung-Tae K, Myung JC, Tae Sung K: Marginal zone B-cell lymphoma of bronchus-associated lymphoid tissue. Chest 2008;133:433-440.

$\checkmark 2$ Thieblemont C, Berger F, Dumontet C, Moullet I, Bouafia F, Felman P, Salles G, Coiffier B: Mucosa-associated lymphoid tissue lymphoma is a disseminated disease in one third of 158 patients analyzed. Blood 2000;95:802806.

- Zucca E, Conconi A, Pedrinis E, Cortelazzo S, Motta T, Gospodarowicz MK, Patterson BJ, Ferreri AJ, Ponzoni M, Devizzi L, Giardini R, Pinotti G, Capella C, Zinzani PL, Pileri S, López-Guillermo A, Campo E, Ambrosetti A, Baldini L, Cavalli F; International Extranodal Lymphoma Study Group: Nongastric marginal zone B-cell lymphoma of mucosa-associated lymphoid tissue. Blood 2003;101:2489-2495.

-4 Thieblemont C: Clinical presentation and management of marginal zone lymphomas. Hematology Am Soc Hematol Educ Program 2005;307-313.

5 Cavalli F, Isaacson PG, Gascoyne RD, Zucca E: MALT lymphomas. Hematology Am Soc Hematol Educ Program 2001;241-258.

-6 Zinzani PL, Magagnoli M, Galieni P, Martelli M, Poletti V, Zaja F, Molica S, Zaccaria A, Cantonetti AM, Gentilini P, Guardigni L, Gherlinzoni F, Ribersani M, Bendandi M, Albertini P, Tura S: Nongastrointestinal low-grade mucosa-associated lymphoid tissue lymphoma: analysis of 75 patients. J Clin Oncol 1999;17:12541258. 
7 Arcaini L, Burcheri S, Rossi A, Passamonti F, Paulli M, Boveri E, Brusamolino E, Orlandi E, Molteni A, Pulsoni A, Cox MC, Orsucci L, Fabbri A, Frezzato M, Voso MT, Zaja F, Montanari F, Pascutto C, Morra E, Cortelazzo S, Lazzarino M: Nongastric marginal zone B-cell MALT lymphoma: prognostic value of disease dissemination. Oncologist 2006;11:285-291.

-8 Bayraktar S, Stefanovic A, Montague N, Davis J, Murray T, Lossos IS: Central nervous system manifestations of marginal zone B-cell lymphoma. Ann Hematol 2010;89:1003-1009.

-9 Cervetti G, Galimberti S, Sordi E, Buda G, Orciulo E, Cecconi N, Petrini M: Significant efficacy of 2-CdA with or without rituximab in the treatment of splenic marginal zone lymphoma (SMZL). Ann Oncol 2009;21:851854.

10 Sam S, Molitch M: The pituitary mass: diagnosis and management. Rev Endocr Metab Disord 2005;6:55-62.

11 Martin-Duverneuil N, Guillevin R, Chiras J: Imaging of gliomas. Cancer Radiother 2008;12:669-675.

-12 Tatomirovic Z, Skuletic V, Bokun R, Trimcev J, Radic O, Cerovic S, Strbac M, Zolotarevski L, Tukic LJ, Stamatovic D, Tarabar O: Fine needle aspiration cytology in the diagnosis of head and neck masses: accuracy and diagnostic problems. J Buon 2009;14:653-659.

13 Sigal DS, Miller HJ, Schram ED, Saven A: Beyond hairy cell: the activity of cladribine in other hematologic malignancies. Blood 2010;116:2884-2896.

14 Takamatsu Y, Suzumiya J, Ogata K, Katayose K, Sasaki H, Ishitsuka K, Kimura N, Tamura K: Cladribine treatment in two-hour intravenous infusion for previously-treated low grade B-cell lymphoma: a pilot study. J Clin Exp Hematop 2009;49:69-75. 